ఠ

CORRIGENDUM

\title{
Cardiac resynchronization therapy pacemaker: critical appraisal of the adaptive CRT-P device [Corrigendum]
}

Daoud GE, Houmsse M. Cardiac resynchronization therapy pacemaker: critical appraisal of the adaptive CRT-P device.

Med Devices (Auckl). 2016;9:19-25.

On page 21, Figure 1, Intrinsic $A V \geq 200 \mathrm{~ms}$ should have been Intrinsic $\mathrm{AV} \leq 200 \mathrm{~ms}$.

Medical Devices: Evidence and Research is an international, peerreviewed, open access journal that focuses on the evidence, technology, research, and expert opinion supporting the use and application of medical devices in the diagnosis, treatment and management of clinical conditions and physiological processes. The identification of novel devices and optimal use of existing devices which will lead to improved clinical outcomes and more effective patient management and safety is a key feature. The manuscript management system is completely online and includes a quick and fair peer-review system. Visit http://www. dovepress.com/testimonials.php to read real quotes from authors. 